\title{
NESTING BIOLOGY OF \\ THE SOCIAL WASP MICROSTIGMUS COMES (HYMENOPTERA: SPHECIDAE, PEMPHREDONINAE)
}

\section{By Robert W. Matthews}

\section{Museum of Comparative Zoology}

Sociality in the Hymenoptera has been achieved independently at least ten times (Wilson, 1966). Of these, the majority have occurred in the Apoidea, which in addition exhibit most of the intermediate stages in the evolution of sociality. While no truly social Sphecidae have been previously recorded, presocial sphecids paralleling both types of social evolution in bees have been reported (Evans, 1964, 1966), and undoubtedly more examples will be found as further studies are made. This paper describes the nesting biology of a unique pemphredonine wasp, Microstigmus comes Krombein (Fig. I), from Costa Rica and presents evidence indicating that it is to be regarded as the first case of well-developed social behavior in the family Sphecidae.

Except for brief accounts by Myers (1934) and Howes (1925, 1933), little is known of the biology of Microstigmus. Myers found eleven $M$. theridii nests suspended from the undersides of Coccoloba pubescens leaves in the forests of Trinidad; each was constructed of reddish fibers taken from the underside of the leaves, loosely bound by strands of a silken material, and suspended from the leaf by a slender coiled pedicel. Nests contained one to eight cells, and the prey was Collembola; some nests were parasitized by pteromalid wasps. Although Myers noted the presence of more than one female in some nests, this fact has apparently been overlooked. Howes gives a very general account of the nests and biology of $M$. guianensis from British Guiana including photographs of nests, which he thought to be made of lichen and moss fragments. Significantly, Howes records only one adult wasp per nest, though he does not state how many nests he observed. However judging from his nest photographs his observations may have involved more than one species.

During the first two weeks of March, 1967, I studied Microstigmus comes on the Osa Peninsula of Costa Rica. This wasp constructs white bag-like nests suspended from the under surface of fan-shaped fronds of the palm Crysophila guagara Allen, a com-

Manuscript received by the editor April 4, 1968 
mon plant in primary forests of that region. Over 40 nests were collected during the course of this study; 27 of these were collected at night, when all adults were presumed to be inside. Up to $\mathrm{I} 8$ cells and ro females were found per nest, with many nests containing more than one female.

\section{THE STUDY AREA}

The study plot, approximately 44 meters square, was in a flat tract of undisturbed Tropical Rain Forest (terminology of Leopold, 1959) south of Agua Buena Creek behind the Tropical Science Center Building, 3.5 miles southwest of Rincón, Osa Peninsula, Puntarenas Province, Costa Rica. The canopy, ranging from 35 to 60 meters in height, was relatively closed. Understory plants were not particularly dense; it was possible to walk through the forest with relative ease.

During the period of study (March 5-I I, I967), relative humidity in the forest was above $80 \%$ both night and day and rain fell briefly nearly every day. The air temperature one meter above ground on a representative day ranged from $22^{\circ} \mathrm{C}$ at 0600 to $27.5^{\circ} \mathrm{C}$ at $\mathrm{I} 2 \mathrm{OO}$.

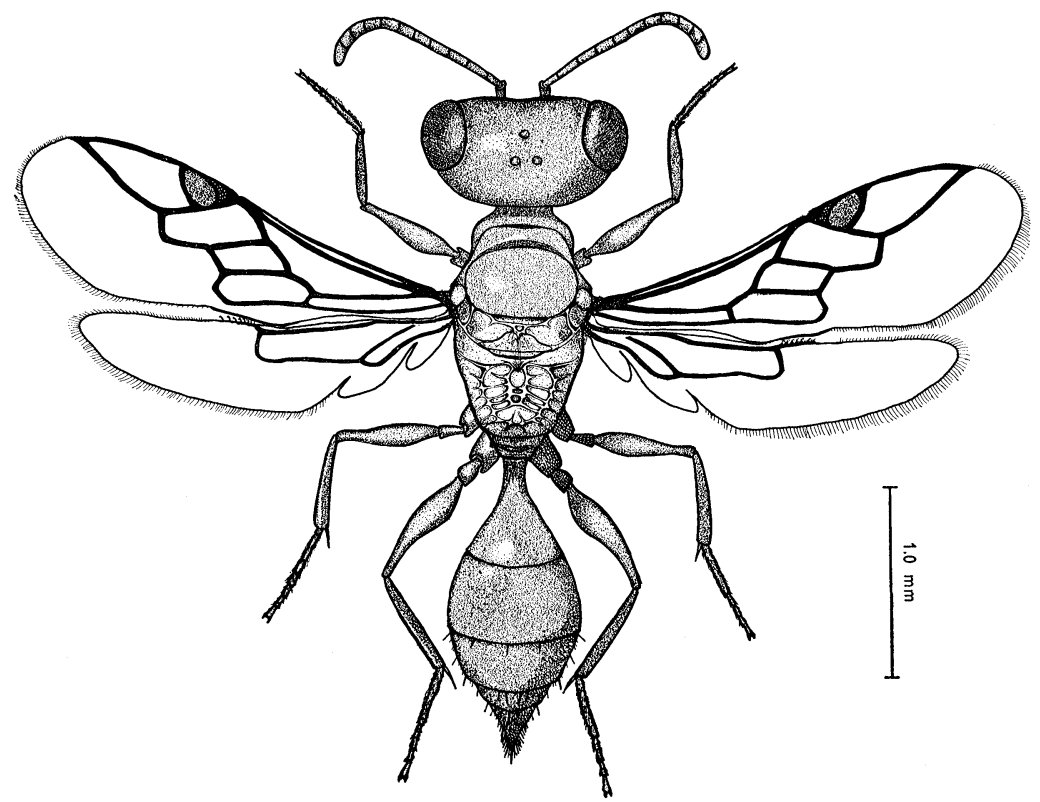

Fig. 1. Female of Microstigmus comes Krombein. 
Eighty-eight Crysophila guagara Allen plants were found in the study area. Figure 2 is a map of their distribution and the distribution of wasp nests in the study area. These plants ranged from seedlings to mature trees approximately 40 feet tall, but nearly half of the plants in the plot were 5 feet or less in height. The number of fronds per plant ranged from 4 on the smallest seedlings to a maximum of 22 on some of the mature trees.

Seventy-four wasp nests from 38 plants were counted in the plot; this was probably less than the total number of nests present, as it was difficult to see nests in the tallest trees. Nests were most easily seen after dark, when they stood out plainly in a flashlight beam against the white undersides of the leaves.

Figure 3 shows the distribution of nests as related to plant size class. Trees of 20 feet or less in height were the preferred nest sites, with the greatest number of nests occurring on trees between 6 and IO feet tall. Sixteen plants had one nest only; I4 had 2 nests; 7 had 3 nests; one had 4 nests and one had 5 nests. This appears to be a high density for a primary forest predaceous insect, but may be a result of the ease of finding nests. By contrast, 800 sweeps with a net in similar vegetation in an adjacent area yielded only one adult of this wasp. While there appeared to be plenty of suitable nest sites available, Figs. 2 and 3 indicate certain sites were preferred. This fact may be significant in the evolution of social behavior in this species since a clumped nest distribution is likely to increase the probability of nest-mates being relatives (see Hamilton, I964).

The nest (Fig. 4) is suspended from near the midrib of the leaf, usually about half the distance to the tip, and approximately at the point where the leaf curvature is greatest. Occasionally there were two active nests on a single leaflet, and once three were found. The broad leaf protects the nest from the rain that would almost certainly destroy an exposed nest. Nests were always on the younger fronds. Older fronds having a large amount of epiphilous algal growth had no active nests although they often showed evidence of having once had them. According to D. H. Janzen (pers. comm.), leaves begin to acquire epiphilous growth at about 5 months of age, suggesting that the life of a wasp nest is less than six months. Indeed, T. C. Emmel (in litt., 22 Aug. 1967) states that he could find no nests in the same locality during August 1967, despite extensive searching.

NEST STRUCTURE AND CONTENTS

Nests are constructed entirely from the waxy bloom coating the 
under surfaces of the Crysophila leaves, and were exclusively confined to these plants. This material is scraped from a roughly oval area approximately $\mathrm{IO} \mathrm{cm}$ in diameter, the nest being attached at the approximate center of the scraped area (Fig. 5). While no extraneous foreign materials were incorporated in any $M$. comes nest, nests of $M$. myersi are reported to have earth pellets incorporated in the walls (Myers, 1934) and nests of $M$. hingstoni (= guianensis) are said to have pellets of rotted wood included in the nest sac (Richards, I932). By contrast, Howes (1925, I933) states that nests of the latter species in British Guiana are made of moss and lichen fragments.

The nest pedicel is loosely spiralled, usually with two coils, and when outstretched measures an average of I $5 \mathrm{~mm}$ (range $12-18 \mathrm{~mm}$ ). The single entrance, located at the nest apex beside the attachment of the pedicel, opens to one side (Fig. 4); in one case there was a double entrance opening to both sides. The nest sac is ovate or obconical; it averaged I $7.4 \mathrm{~mm}$ long (range $\mathrm{I} 2-26 \mathrm{~mm}$ ) and $12.1 \mathrm{~mm}$ (range $8-15 \mathrm{~mm}$ ) at its widest diameter. The outer surface varied in texture from relatively smooth to granulose. Only loosely bound together, the flocculent bottom half of the nest probably serves as a reservoir of material used for cell construction. In basic structure, $M$. theridii nests (Myers, 1934) are similar, measuring $12 \mathrm{~mm}$ long with a coiled pedicel of the same length. Photographs of supposed $M$. guianensis nests given by Howes (1933, repeated in Clark, 1937) show a very short, uncoiled pedicel. However, unless pedicel length is highly variable in the species, these nests are probably incorrectly ascribed. Rather, an earlier photograph of a nest with a very long, apparently uncoiled pedicel (Howes, I925, p. 276) probably represents the true $M$. guianensis nest, for this agrees closely with the nest of $M$. hingstoni, recently placed in synonymy under $M$. guianensis (Krombein, I967), having a pedicel measuring $60 \mathrm{~mm}$ (Richards, I932).

The upper half of the nest is hollow and covered internally with a smooth translucent coating, giving rigidity to the sac. The same material is found on the pedicel and lip of the entrance, and on the internal surfaces of the cells. The coating of the cells with a transparent substance seems to be unique in the Sphecidae but parallel cases are known in some bees (e.g. Colletidae). It is probable that the pedicel may be entirely secreted, for Myers (1934) noted that the reddish $M$. theridii nest sacs were held together by whitish silk-like strands which became thicker toward the nest apex 


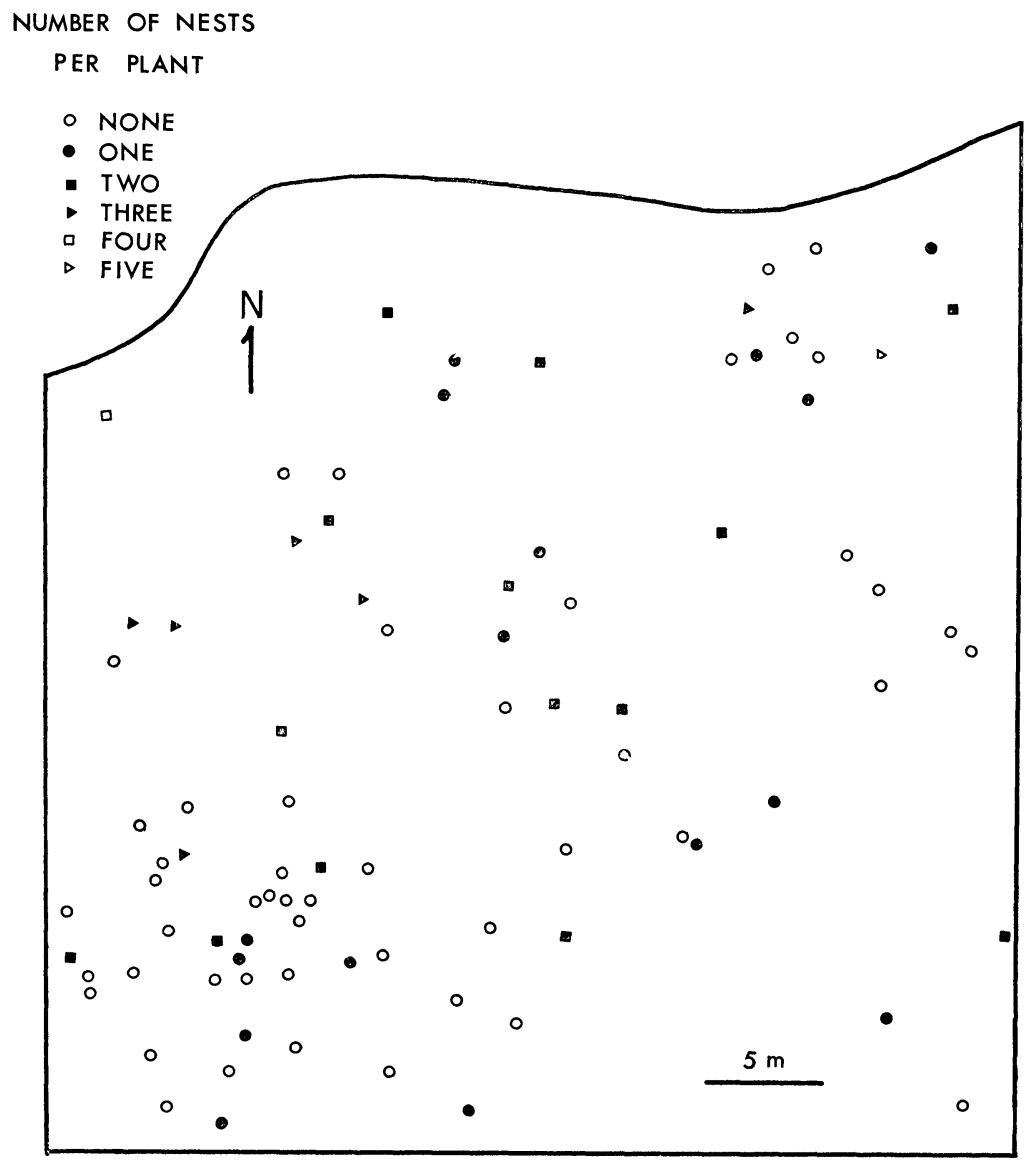

Fig. 2. Distribution of Crysophila palms and M. comes nests in the study plot near Rincón, Costa Rica. Each symbol represents a single Crysophila plant.

and "wholly predominated in the pedicel which looked whitish in consequence". However, lack of differential coloration in the secretion and plant fibers obscured such a distinction in $M$. comes.

The source of this translucent material is unknown; however, wasps frequently worked up and down the pedicel and about the entrance, stroking and tamping these areas with thrusts of the abdomen (see Nest Maintenance and Defense, below). Examination of the abdomen tip reveals a dense brush-like cluster of hollow, 


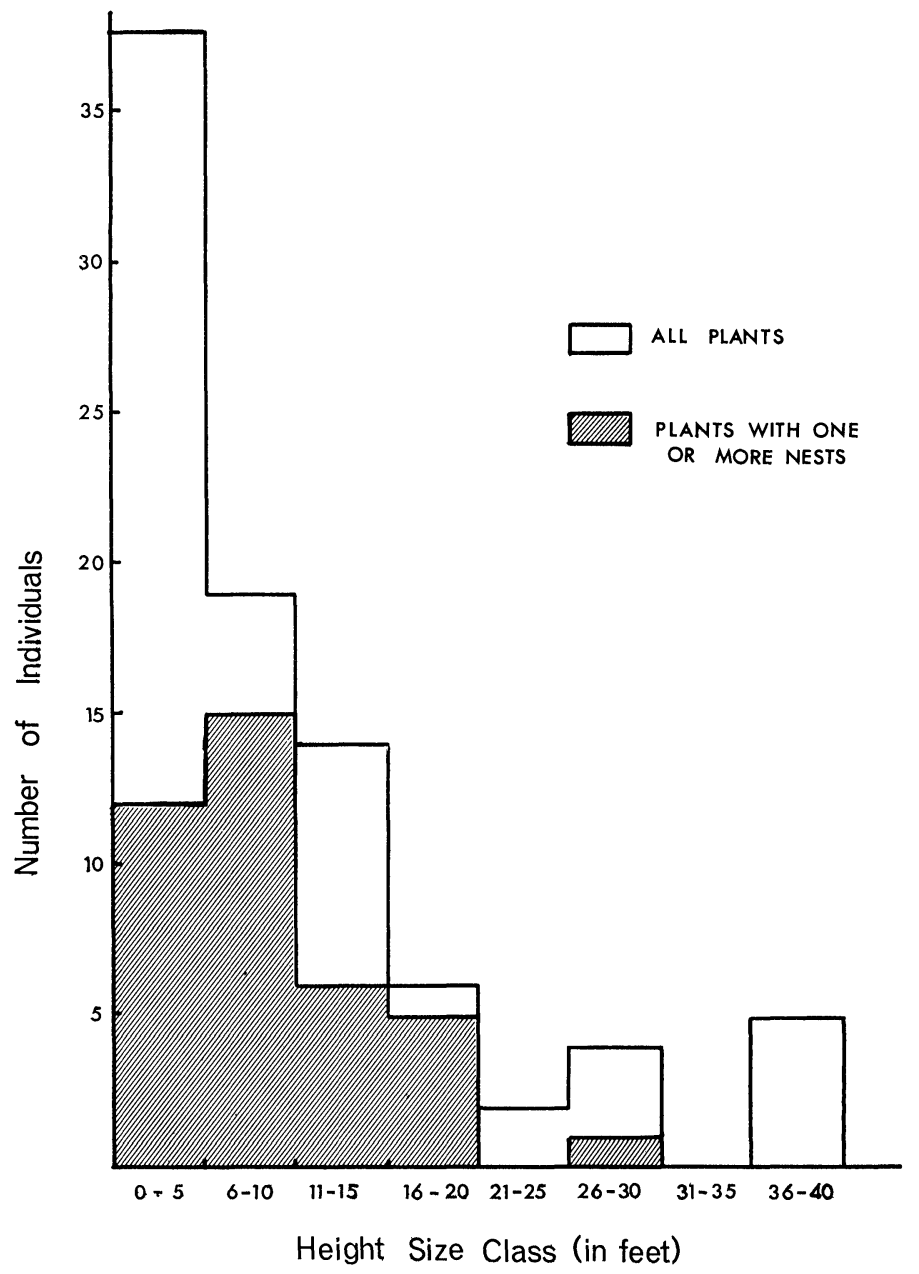

Fig. 3. Histogram of height size distribution of Crysophila guagara and distribution of $M$. comes nests in the study plot.

blunt-tipped setae at the end of the apical tergite (Fig. 6). Associated with this setal brush is a rather large gland, the cells of which each have a well developed cuticular vesicular organelle and tubule (Fig. 7) similar to that described for the defensive gland of Eleodes longicollis by Eisner et al. (1964). Several tubules fuse and empty into the hollow bases of each of the brush setae. This distinctive 
glandular apparatus is very prominent in tergites treated with I0\% $\mathrm{KOH}$ and viewed under high magnification. While the function of the gland is not yet known, it may prove to be the source of secreted material applied by the setal brush.

Within the nest are the pocket-like cells, situated in the lower half of the sac 8 to II $\mathrm{mm}$ below the entrance. Initially they are arranged about the periphery of the nest, with the central area gradually filled as the number of cells increases. Each cell, approximately cylindrical in shape, is about $4 \mathrm{~mm}$ long and $\mathrm{r} .8-2.1 \mathrm{~mm}$ wide at the mouth. Diagrams representing cell distribution and contents of a large and small nest are given in Figs. 8 and 9.

A total of 139 cells (mean, 3.6 cells per nest) were found in 39 dissected nests; the largest number of cells in a single nest was 18 . All but 7 nests contained 4 or fewer cells; six nests contained no cells, but four of these also lacked adults, indicating that they may have been abandoned. Ten nests contained but one cell.

The cell contents from night-collected nests are summarized in Table. I. Typically a four-celled nest would contain one pupa, one mature larva, one fully provisioned cell with egg or newly hatched larva, and one partially provisioned cell. Indeed, no two cells of the same nest were ever found to be in the same state of development, a fact also noted for M. theridii (Myers, 1934), suggesting that only one cell is constructed and provisioned at a time. Even in a r 3-celled nest that contained io adult females, only 2 cells had eggs (each at a distinctly different stage of development) and a third cell was partially provisioned.

Cells of $M$. comes nests were mass provisioned with Collembola of the families Entomobryidae and Sminthuridae (Table 2). Use of Collembola as prey is, so far as known, unique to Microstigmus within the Sphecidae; however, they are an abundant and probably little exploited food source in the tropical rain forest.* The Collembola, averaging about $\mathrm{I} \mathrm{mm}$ in length, were virtually all sub-adult; in completed cells with eggs, the number of Collembola per cell averaged 46 (range $3 \mathrm{I}-58 ; \mathrm{N}=22$ ). The prey are packed together into a compact, more or less spherical mass, but can be easily separated in alcohol. Myers (1934) recorded predominantly Entomobryidae as prey of $M$. theridii on Trinidad, one cell containing about

\footnotetext{
* Since this paper was written, I have received an unusual nest and adult of an undescribed species of Microstigmus from the same locality, in which the prey is thrips. The single provisioned cell contained 70 thrips, mostly immature instars.
} 


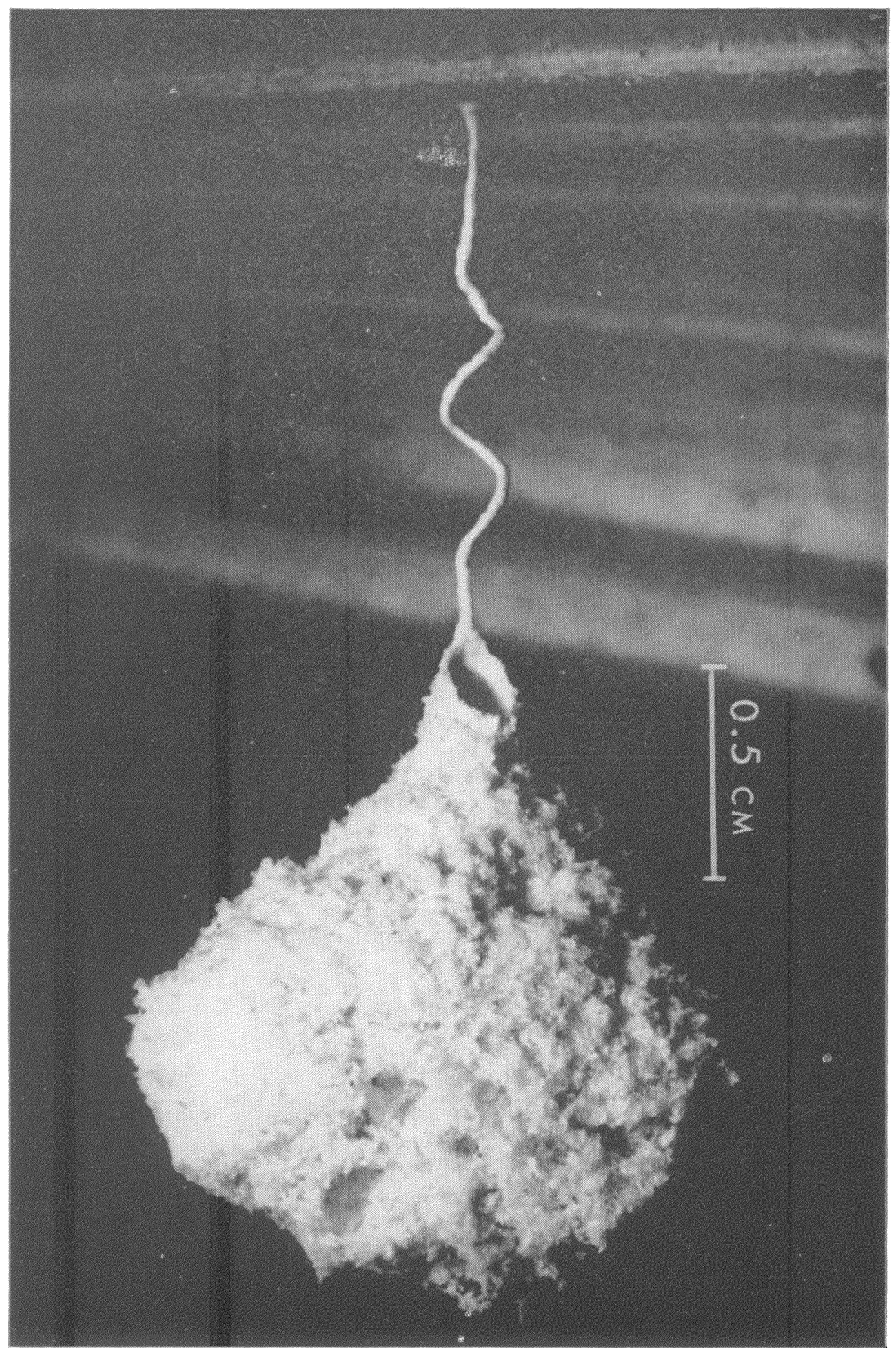

Matthews - Microstigmus comes 
30 individuals of varying ages; he noted that the prey were frequently dismembered, presumably by the wasps, but no such dismemberment was noted for $M$. comes prey.

Completed food masses (Fig. IO) averaged $1.2 \mathrm{~mm}$ in diameter and were firmly stuck to one side of the cell near its midpoint. In every case these food masses were of mixed species composition: 6 species were found in I cell, 5 species in Io cells, 4 species in 8 cells, 3 species in 3 cells, and 2 species in 2 cells. Two of the six species, Lepidocyrtus sp. $X$ and Paronella sp., comprised $70 \%$ of the prey sample (Table 2).

The hunting behavior of $M$. comes was not observed. However, $\mathrm{R}$. J. Snider (pers. comm.) states that, insofar as known, the species used as prey are all epigean and sun-loving; furthermore, all are brightly and distinctly colored and (except Deuterosminthurus) possess scales which reflect in sunlight. These facts suggest that $M$. comes hunts primarily among low vegetation, probably in sun flecks, and relies upon visual cues in its search for prey.

The sausage-shaped egg measures $\mathrm{I} .4 \mathrm{~mm}$ long and $0.4 \mathrm{~mm}$ wide at the middle; it is draped over the food mass and attached by one end, the other end projecting free (Fig. Io). The egg is not laid until provisioning is complete; normally but one egg was found per nest (IO of 15 nests with eggs), but four nests had two eggs and one exceptional nest had 3 cells with eggs.

Freshly provisioned cells are weakly closed with a rather haphazard crisscrossing fabric consisting of a few secreted strands. However, cells containing mature larvae, prepupae and pupae are open. Prepupae and pupae are always found oriented with the head in the bottom of the cell, the anus attached at the cell opening. As in most other known members of the Pemphredoninae, no cocoon is spun. The distinctive larva of $M$. comes is described elsewhere (Evans and Matthews, I968).

Nothing is known regarding the relative lengths of the developmental stages of $M$. comes. Attempts to rear eggs and larvae in gelatin capsules failed, probably due to dessication. However, several adults subsequently emerged from pupae in nests kept in covered petri dishes. Howes (1933) reports that eggs of $M$. guianensis hatch in two days and the larvae feed for one week, then pupate and emerge as adults two weeks later.

Explanation of Plate 2

Fig. 4. Microstigmus comes nest attached to underside of a Crysophila frond. Note nest entrance and doubly coiled pedicel. (Photo by C. W. Rettenmeyer.) 


\section{ADULT BEHAVIOR}

Provisioning. - The earliest any wasps flew from the nest in the morning was just before 0800 hours, the times of first departures on three consecutive days being $0806,075 \mathrm{I}$ and 0824 . Altogether I 5 trips for prey were timed; these required from 8 to 140 minutes, the mean being nearly 37 minutes. At this rate, it would require a single female about three days to collect the 46 Collembola needed to provision the average cell. In one nest observed continuously, the two females made a total of 13 trips for prey over a period of 7 hours 28 minutes.

Table 1. Summary of contents of 22 active Microstigmus comes nests, collected at night and preserved immediately.

\begin{tabular}{|c|c|c|c|c|c|c|c|c|}
\hline $\begin{array}{c}\text { Number } \\
\text { of Adults: } \\
\text { Female Male }\end{array}$ & Pupae & $\begin{array}{r}\text { Immatu } \\
\text { Prepupae }\end{array}$ & $\begin{array}{l}\text { ures: } \\
\text { Larvae }\end{array}$ & Eggs & $\begin{array}{l}\text { Incom- } \\
\text { plete } \\
\text { Food } \\
\text { Masses }\end{array}$ & $\begin{array}{c}\text { Para- } \\
\text { sites }\end{array}$ & Empty & Total \\
\hline 56 & 28 & 5 & 14 & 17 & 11 & $5^{1}$ & 2 & 81 \\
\hline
\end{tabular}

${ }^{1}$ Parasite egg on mature $M$. comes larva in one case.

When the females returned to the nest they invariably alighted on the side of the nest, then quickly crawled up and inside. This behavior made it possible to determine whether prey was being carried, and to ascertain that it was held in the mandibles. Generally the female spent less than a minute at the nest between prey hunting trips. Usually she was in and out again quickly, having spent less than 5 seconds inside. This was followed by walking slowly over the outside of the nest for up to 60 seconds before departure, usually visibly grooming the mouthparts during much of this time. The observed wasps never departed directly from the nest entrance. Often the females made brief "orientation" flights before disappearing; these consisted of two or three circular flights about $5 \mathrm{~cm}$ beneath the nest.

Nest Maintenance and Defense. - All nests observed were found to have at least one adult present at all times, and wasps were active on the outside of the nest throughout the day. This extra-nest activity was classified as "inspection" trips or "maintenance" trips.

Usually, "inspection" trips were brief, with the wasp crawling once around the nest quickly from top to bottom or in a spiral pattern and then reentering the nest. These trips were made at irregular intervals throughout the day and seldom did five minutes elapse without a wasp crawling on the nest surface at least once. In one representative hour, 29 "inspection" trips were made, re- 
quiring from 4 to 36 seconds each (average, 8.5 seconds). During another hour, 22 trips were made, ranging from 4 to 50 seconds (average, I I seconds). Apparently both sexes participate in this behavior, and on occasion two or three individuals came outside almost

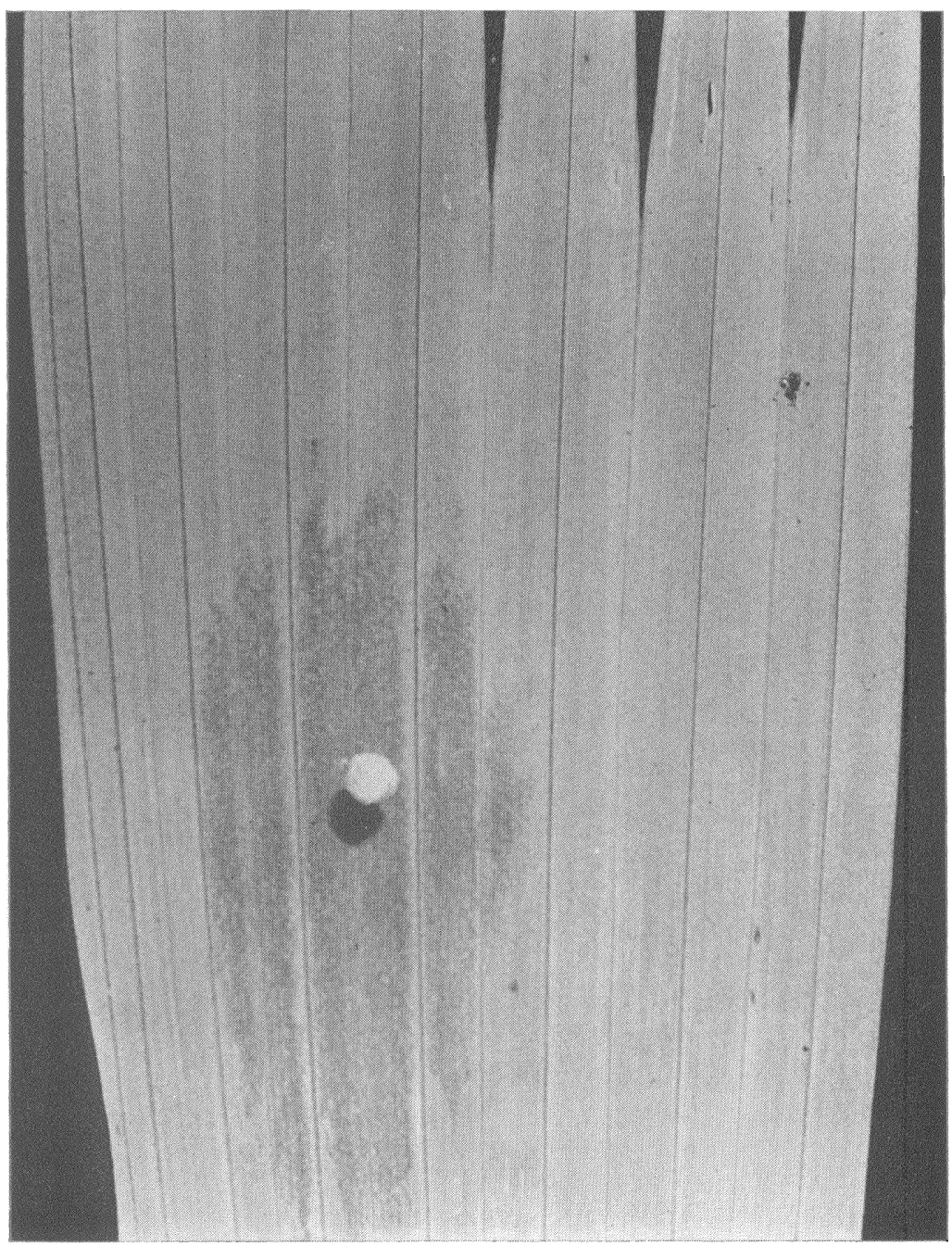

Fig. 5. Underside of a Crysophila leaflet and attached nest; note oval area from which nest material has been scraped. (About natural size.) (Photo by C. W. Rettenmeyer.) 
simultaneously. The significance of this "inspection" behavior may be protection against predators and parasites by enchancing the likelihood that an intruder will be encountered before endangering the nest.

In one instance a small beetle larva was deliberately placed on the nest. Its movements quickly attracted the two wasps inside the nest. At the first encounter the wasps attempted to grasp the intruder in the mandibles but were repelled. There followed a period of extensive rapid crawling over the nest during which the wasps encountered the intruder several times but failed to successfully remove it. After about 7 minutes, the larva dug into the loose material in the bottom of the nest, and about 2 minutes later the wasps returned to the inside of the nest and no longer seemed excited. The following day the beetle larva emerged from the nest and again created considerable excitement until it again burrowed inside the nest about 4 minutes later. When the nest was collected that afternoon, the beetle larva was found inside. On another occasion, a female braconid wasp parasite (see following section) was observed to crawl down the pedicel and then run quickly onto the nest surface. In less than two seconds, a Microstigmus emerged from the nest, presumably stimulated by the braconid's movements. In circling the nest it encountered the braconid almost immediately, causing the parasite to fly.

"Maintenance" trips took three forms. One type involved carrying small chunks of fibrous material from the interior of the nest to the outside, where they were dropped. Typically this behavior occurred in spurts, several such pieces being carried out over a three or four minute period. The material to be discarded was carried in the mandibles and usually down to the bottom half of the nest. Then, while standing on the hind two pairs of legs, the wasp removed the material from its mouthparts with the fore tarsi and the material floated away.

Explanation of Plate 3

Fig. 6. Dorsal view of $M$. comes ( $q$ ) apical tergite, treated with $10 \%$ $\mathrm{KOH}$. Note cluster of blunt-tipped setae ( $\mathrm{sb}$ ) at apex; cuticular portions of associated gland ( $\mathrm{gl}$ ) are also visible. Central "line" (arrow) is edge of tergite, bent back upon itself.

Fig. 7. Cuticular vesicular organelles ( $\mathrm{VsO}$ ) and associated tubules $(\mathrm{Tu})$ isolated from glands of apical tergite by $\mathrm{KOH}$ treatment. Note the indistinct peripheral fringe swellings (PF) covering surface of each organelle. 

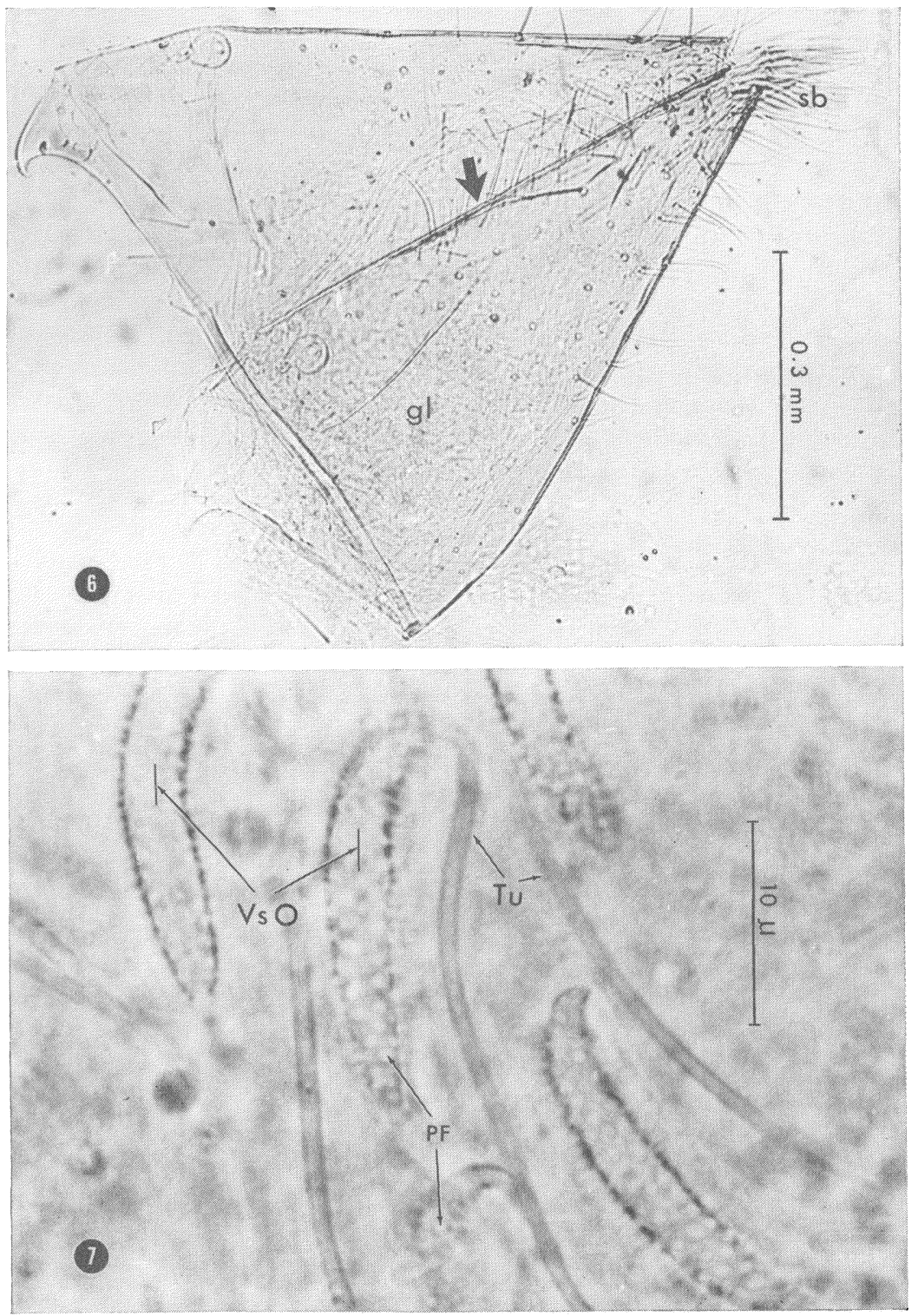

Matthews - Microstigmus comes 
Two other types of "maintenance" involved work on the exterior of the nest or pedicel. In one the wasp worked on the nest proper, removing numerous small pieces of nest material from the surface with the mandibles and discarding them in the manner described above. In one such case, a wasp pulled off 37 pieces of nest in less than eight minutes. The third variation of "maintenance" behavior consisted of work primarily on the pedicel or about the nest entrance. When on the pedicel the wasp repeatedly crawled up and down it in a spiraling manner, with the body axis roughly perpendicular to the nest pedicel. Here the tip of the abdomen was used extensively, often vigorously stroking or tamping the substrate, suggesting that the setal brush and associated gland may function in this activity. This latter behavior was noted primarily in the early morning, and excursions often lasted Io or more minutes.

\section{PARASITISM}

Nine cells in five nests were found to be parasitized by the braconid wasp Heterospilus microstigmi. This wasp was first described by Richards ( I935) from $M$. theridii nests on Trinidad, and my specimens have been compared with the type in the British Museum by G. E. J. Nixon. While no other parasites of $M$. comes were found in Costa Rica, Myers (1934) records a pteromalid wasp as a frequent parasite in $M$. theridii nests from Trinidad but does not mention any braconid parasites.

The parasitized nests contained six pupae, two larvae and an egg. Adults subsequently emerged from some pupae. While the larvae and egg could not be positively identified, there seems little doubt that they were braconids. The egg was found attached to the ventral surface of a mature Microstigmus larva between the head and thorax. It measured $0.4 \mathrm{~mm}$ long and $0.1 \mathrm{~mm}$ wide at the middle, and was slightly tapered at one end. The larva was distinguished by the presence of two prominent tubercles dorsally. An opaque white cocoon was spun by the parasite, usually near the bottom of the cell.

Adult $H$. microstigmi females were seen at the wasp nests on six occasions and probable oviposition was observed once. On this occasion, the braconid crawled slowly around the nest with the wings held vertically over the thorax for approximately io minutes. During this time she inserted her ovipositor completely into the nest several times, usually just in and out quickly (about 2 seconds). Whether these represented probes or repeated actual ovipositions is unknown. Eventually she left the nest, and flew slowly along the undersides of two other leaflets of the same leaf, apparently searching for other 
nests. Soon she returned to the same nest, first darting at it two or three times from $5 \mathrm{~cm}$ away, and then landing on it. At that point the wasp was collected. On another occasion three female $H$. microstigmi were observed at different nests in the study area during one fifteen minute period. One was seen to be effectively repelled by the nest residents before any oviposition could be attempted (see previous section).

Table 2. Collembola prey taken by $M$. comes, based on 1197 individuals from 35 cells, 24 of which were "complete", as defined by presence of egg or newly hatched larva. "Presence" = number of complete cells in which species occurred. Identifications by R. J. Snider of Michigan State University; specimens are deposited in his collection.

\begin{tabular}{lccc} 
& $\begin{array}{c}\text { No. of individuals } \\
\text { in all cells }\end{array}$ & $\begin{array}{c}\% \text { of total no. } \\
\text { of Collembola }\end{array}$ & Presence \\
\hline Entomobryidae & & & \\
Entomobryinae & & 0.4 & 3 \\
$\quad \begin{array}{l}\text { Drepanocyrtus } \text { sp. } \\
\text { Lepidocyrtus } \text { sp. X }\end{array}$ & 442 & 36.9 & 23 \\
$\begin{array}{l}\text { Lepidocyrtus } \text { sp. Y } \\
\text { Lepidocyrtus } \text { sp. Z }\end{array}$ & 143 & 11.9 & 17 \\
$\begin{array}{l}\text { Paronellinae } \\
\text { Paronella } \text { sp. }\end{array}$ & 41 & 3.4 & 11 \\
Sminthuridae & 392 & 32.7 & 24 \\
Sminthurinae & & & \\
$\quad$ Deuterosminthurus sp. & 174 & 14.5 & 23
\end{tabular}

Other Nest Inhabitants. - Four nests were found that had apparently been used by a solitary wasp and had the entrance plugged with mud. The interior of each of the nests also had been partially coated with mud. One contained ro immature paralyzed spiders belonging to the Theridiidae and Tetragnathidae (det. H. W. Levi); an egg was attached to the right side of the abdomen of one spider. Another nest contained a horizontally situated brownish cocoon from which an unidentified ichneumonid parasite emerged. A third contained a similar cocoon from which an adult had previously emerged. The fourth was empty except for a mud lining.

\section{DISSECTION OF FEMALES}

The females from each night-collected nest were killed by preserving in either Bouin's solution or chloral hydrate fixative; subsequently, dissections of the reproductive system were made. Data on the ovary conditon of females from the largest colonies are summarized in Table 4 ; due to the small size of the wasp, the sperma- 
thecae were often overlooked or lost, and reliable information on spermathecal condition was not obtained.

Normally, there are three ovarioles per ovary, each with never more than a single mature egg at one time. Egg capacity is low, with a maximum of four visible oocytes per female; no two oocytes were ever at the same stage of development (as judged by length). A mature oocyte is relatively large, occupying nearly two thirds of the abdomen. These data appear to agree with the trend noted by Iwata (1964) - presocial Hymenoptera often tend to produce fewer, larger eggs than their solitary relatives.

\section{THE QUESTION OF SOCIALITY}

A discussion of this important subject is given in detail elsewhere (Matthews, I968) but will be summarized here. Half of the active night-collected nests were found to contain more than one adult female (see Table 3), with as many as Io females present in a single nest. In the night-collected nests, a total of 56 females and 19 males were obtained, a sex ratio of about $3: 1$. One relationship examined was that between nest size (as indicated by the number of immatures present) and number of adult females in the nests. The data, in terms of mean reproductivity per colony and reproductivity per female (see Michener, 1964), are presented in Table 3 for night-
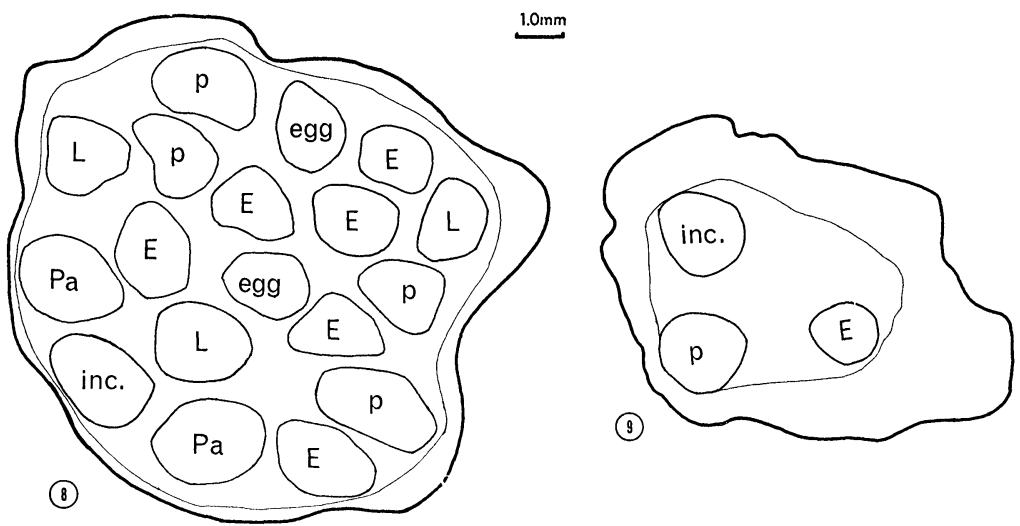

Figs. 8 and 9. Diagrammatic cross-sections of $M$. comes nests. $\mathrm{E}=$ empty; inc $=$ incomplete food mass; $\mathrm{L}=$ larva $\mathrm{Pa}=$ parasite $\mathrm{p}=$ pupa. 8. The largest nest, showing distribution and contents of the 18 cells; large number of empty cells is due to adult eclosion after collection and accidental loss of cell contents during dissection. 9. A typical 3-celled nest; note greater thickness of nest wall. 
collected nests containing one or more adult females. While fragmentary, they suggest that, as in other social insects, colony reproductivity rises with colony size. However, reproductivity per female appears to remain more or less constant regardless of colony size, a situation seemingly analagous to that of Pseudagapostemon divaricatus, a communally nesting bee which lacks morphological caste determination (Michener, 1964). In contrast, more highly evolved hymenopterous societies have a relatively high productivity per female when colony size is small, this steadily decreasing as the number of nest inhabitants rises. It should be remembered that the data reported herein represent a census of nests of various sizes taken at a given point in time; no information was obtained for nests earlier or later in the season.

Evidence strongly suggests that cooperative provisioning occurs among $M$. comes females. As previously mentioned, no two cells of the same nest were ever found to be at the same stage of development, a fact also noted for $\boldsymbol{M}$. theridii (Myers, 1934). Recalling also that the cells are mass-provisioned, it is significant to note that no nest, regardless of size or number of females present, was found to have more than one incompletely provisioned cell. Observations at a nest containing two females and a male showed both females carrying prey to the nest; when the nest was collected later the same day, only one cell contained prey. Thus it appears reasonably certain that foraging females from a single nest cooperate and provision one cell at a time.

Similarly, the individuals present in multi-adult nests cooperatively participate in its defense, responding almost instantaneously to any disturbance (as noted above, see Nest Maintenance and Defense). Of significance in this regard is the fact that all such nests observed in the field had at least one adult present at all times. While the sexes of these adults were not confirmed, the indication is that some division of labor between foraging and nest maintenance and protection may exist. ${ }^{1}$ )

Evidence for the existence of parental care was discovered rather fortuitously. Cells in the nests, at first loosely closed, are apparently reopened while the larvae feed. The absence of fecal pellets or meconial remains in larval or pupal cells in the night-collected

\footnotetext{
${ }^{1}$ Wasps in the genera Trypargilum and Pison (Trypoxyloninae) are exceptional in being the only sphecids in which males are known to actively participate in nesting. Nests generally contain a pair of wasps, the male guarding the entrance while the female is away. (See Medler, 1967 and Masuda, 1939).
} 
nests was not particularly noted at first; however, when nests kept (without adults) in covered petri dishes were later dissected, a striking accumulation of fecal pellets in larval cells was noticed. This suggests that there is frequent contact between parent and offspring. Further, although the manner by which prepupae and pupae become uniformly secured by the anus to their cell rims is as yet unanswered, the possibility exists that the parents may be involved.

Table 3. Relation between nest size and number of adult females present, based on 22 active night-collected nests. Parentheses indicate number of nests on which figures are based.

\begin{tabular}{cllllllll} 
& \multicolumn{7}{c}{ Number of females per nest } \\
\cline { 2 - 8 } $\begin{array}{c}\text { Mean number } \\
\text { of immatures }\end{array}$ & $1.9(11)$ & $1.7(3)$ & $7.3(3)$ & $4.0(1)$ & $2.0(2)$ & $9.0(1)$ & $12.0(1)$ \\
$\begin{array}{c}\text { Reproductivity } \\
\text { per female }\end{array}$ & 1.9 & 0.8 & 2.4 & 1.0 & 0.4 & 1.5 & 1.2
\end{tabular}

A nagging question in any discussion of insect sociality is whether division of labor exists. Significant morphological differences between $M$. comes females from the same nest have yet to be found. No dimorphism exists in either wing length or head width. However, this does not exclude the possibility of behavioral or physiological caste differences as have been found in some bees (Michener, I958) and wasps (Evans, 1958). Moreover, it seems to be a general rule in each group of social Hymenoptera that the degree of morphological difference between the queen and worker castes lags behind specialization as judged by other features. Thus, it would be especially valuable to know whether egg laying in the larger nests was restricted to one female or whether several females might participate.

In nearly all of the larger colonies censused (see Table 4) one female exhibited a strikingly developed oocyte, in contrast to her nest-mates whose most developed oocytes were considerably smaller (less than half as long in 5 of the 8 nests). In fact, one female in each of four nests $(5-2,5-3,24-\mathrm{I}, 72-\mathrm{I})$ had two oocytes of a length greater than the largest oocyte to be found in any of her nest-mates. Thus it appears that, regardless of the number of females present in a colony, at any one time there is but one mature ovarial egg available, correlating with the earlier observation that one cell is provisioned at a time. More significantly, the data suggest that some degree of reproductive dominance (division of labor) may exist with one female per nest doing most of the egg laying. Data on rate of oocyte development and maturation would, of course, be desirable. 
The only available information on this point is that of Iwata (1964) who found that many presocial Hymenoptera have a relatively low egg maturation rate. Additionally it would be good to know the spermathecal condition of each female and the rate of development of laid eggs. Certainly the available data for $M$. comes do not rule out the possibility that cells in the larger nests ( 3 cells with eggs in one case) could be the product of more than one female.

Table 4. Ovarian condition of females from eight $M$. comes nests with three or more female adults present, ranked in order of decreasing size of largest oocyte. Parentheses indicate number of visible oocytes. $\mathrm{nr}=$ not recorded. $\mathrm{U}=$ no visible oocyte development. $\mathrm{D}=$ destroyed accidentally.

\begin{tabular}{|c|c|c|c|c|c|c|c|c|c|}
\hline \multirow{3}{*}{$\begin{array}{l}\text { Nest } \\
5-1\end{array}$} & \multicolumn{9}{|c|}{ Oocyte lengths (in $\mathrm{mm}$ ) } \\
\hline & $\begin{array}{l}\text { Total } \\
\text { cells }\end{array}$ & $\begin{array}{c}\text { Longest } \\
\text { two for } \\
\text { most } \\
\text { mature } ᄋ\end{array}$ & & For ot & her fema & ales pres & ent in 1 & nest & \\
\hline & 4 & $\begin{array}{l}0.75(4) \\
0.23\end{array}$ & $0.30(2)$ & $0.18(1)$ & & & & & \\
\hline 11 & 7 & $\begin{array}{c}0.18(2) \\
\mathrm{nr}\end{array}$ & $0.15(2)$ & $0.13(1)$ & $0.13(2)$ & & & & \\
\hline $24-1$ & 4 & $\begin{array}{l}0.38(3) \\
0.30\end{array}$ & $0.15(2)$ & $0.10(1)$ & $0.08(2)$ & & & & \\
\hline $5-4$ & 1 & $\begin{array}{c}0.33(2) \\
\mathrm{nr}\end{array}$ & $0.23(3)$ & $0.20(1)$ & $0.18(1)$ & $0.15(1)$ & & & \\
\hline $30-1$ & 3 & $0.27(1)$ & $0.20(1)$ & $0.10(2)$ & $0.10(1)$ & U & & & \\
\hline $5-2$ & 10 & $\begin{array}{l}0.43(4) \\
0.18\end{array}$ & $0.15(2)$ & $0.15(2)$ & $0.13(1)$ & $0.08(1)$ & & & \\
\hline $5-3$ & 9 & $\begin{array}{l}0.68(3) \\
0.25\end{array}$ & $0.18(2)$ & $0.13(2)$ & $0.10(1)$ & $\mathrm{U}$ & $\mathrm{D}$ & & \\
\hline $72-1$ & 13 & $\begin{array}{l}1.00(3) \\
0.55\end{array}$ & $0.20(3)$ & $0.13(2)$ & $0.13(1)$ & $0.10(2)$ & $0.10(2)$ & $0.08(2) \quad 3 \mathrm{~L}$ & $3 \mathrm{U}$ \\
\hline
\end{tabular}

As yet unanswered are the questions of how the multi-adult colonies of $M$. comes arise and how sociality may have evolved in this species. Since no information is available on colony change through time, colony founding, or adult longevity, presence of more than one adult per nest could be interpreted either as association of adults of the same generation or as offspring associating with previously established nests. However, half of the active nests censused contained but a single adult; further, although many new adults emerged during the period of study, no nests under construction were found. It therefore seems likely that offspring do associate with previously established nests. That parental and offspring adult lives overlap also seems probable since 3 of the Io females in the largest 
nest (72-I) had no visible oocytes, suggesting that they were newly emerged, possibly offspring from that nest. However, in contrast to most Hymenoptera, wing and mandible wear in $M$. comes seemed to be non-existant, and hence of no use as an indicator of the relative ages of the wasps. Relative pigmentation was a potential indicator of age, and many adults appeared to be in a teneral condition, but such a character is difficult to quantify.

Thus, if social behavior is defined as activity of an individual benefitting the young of another of the same species (Richards, I965; West, I967), Microstigmus comes can certainly be regarded as a truly social sphecid wasp. Most notable in this regard are the regular occurrence of more than one adult in a single nest and the demonstration of parental care (provisioning and defense) of brood by more than one adult female. Even if the more stringent criterion of sociality, that of reproductive dominance (division of labor) is employed, the data are suggestive that this is the case. Why Microstigmus seems to have gone so far along the road to sociality is not entirely clear. If the theory of Hamilton (1964) is correct, a fact of potential significance in the social evolution of $M$. comes

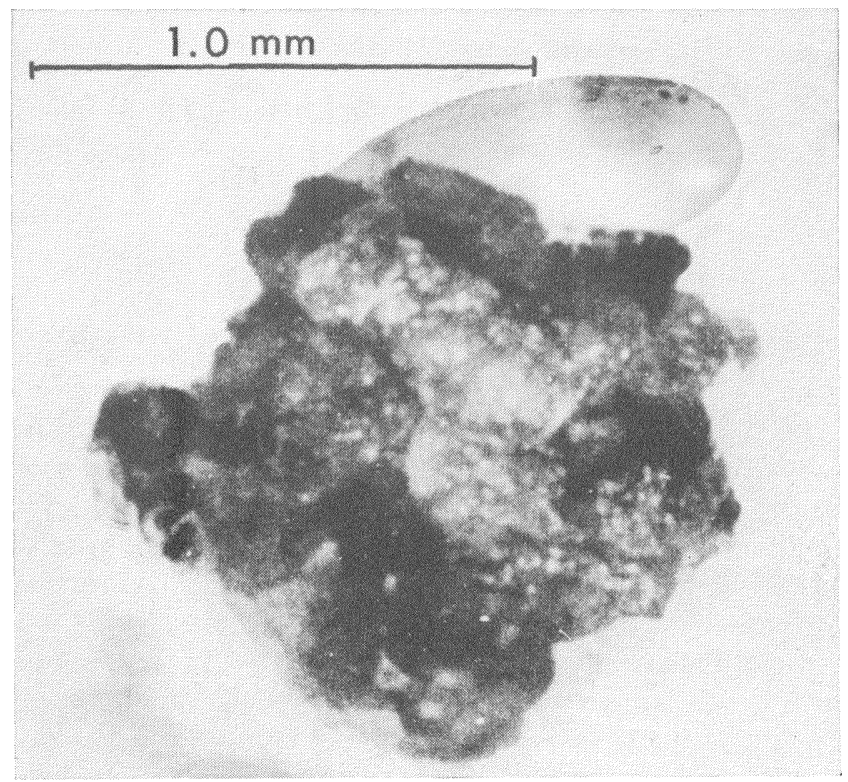

Fig. 10. Freshly provisioned cell of $M$. comes showing spherical food mass of Collembola and egg. (Photo by C. W. Rettenmeyer.) 
is the apparent clumped nest distribution, inasmuch as it would increase the likelihood that nest-mates are relatives. Also, evolution of a pendent type of nest, unique among the Sphecidae, seems certain to have been a significant step, especially as it allows an opportunity for parent-offspring interactions. Perhaps correlated with this type of nest is the presence in Microstigmus of a distinctive setal brush in place of a pygidial plate on the apical tergite of the female. Except for Spilomena, the closest relative of Microstigmus (K. V. Krombein, pers. comm.), all genera of the Pemphredoninae I have examined show varying degrees of development of the pygidium; those for which biological information exists nest in the soil or in various preformed cavities and presumably use the pygidium to pack soil or tamp cell partitions.

\section{SUMMARY}

Nests of Microstigmus comes Krombein from Costa Rica contained as many as 18 adults of both sexes, and up to 18 cells with brood of all ages present; half of the 22 active nests collected at night (when all wasps were presumed to be inside) contained more than one adult female. Observations on adult behavior in provisioning, defense and nest maintenance give evidence of parental care and cooperation; ovary dissections indicate some form of reproductive dominance (division of labor) among females from the same nest, although no external morphological differences are apparent. These facts suggest that this is the first fully social wasp of the family Sphecidae.

$M$. comes is, furthermore, unique among Sphecidae in its pendent bag-like nests, constructed entirely of vegetative material scraped from beneath fronds of the palm Crysophila guagara Allen and reinforced by a transparent secretion, and in its use of Collembola as prey; cells are mass-provisioned. A dense cluster of hollow setae (setal brush) on the apical abdominal tergite and an associated sternal gland are described and hypothesized to be involved in nest construction.

An external parasite of $M$. comes larvae, the braconid Heterospilus microstigmi Richards was reared from some nests, and oviposition by this wasp was observed.

\section{ACKNOWLEDGEMENTS}

This research was done as part of a course in Tropical Insect Ecology offered by the Organization for Tropical Studies during February and March, 1967. I thank Drs. H. E. Evans, E. O. Wilson, M. J. West Eberhard and C. D. Michener for much con- 
structive criticism of the manuscript and gratefully acknowledge the assistance of Drs. D. H. Janzen, C. W. Rettenmeyer and T. C. Emmel during the field aspects of the study. I am indebted to Dr. K. V. Krombein for his prompt description of the wasp and to Dr. P. M. Marsh for assistance with the identification of the parasite. Mr. R. J. Snider kindly identified the Collembola prey. Finally I am grateful to Miss N. K. Lind and Mr. W. C. Kerfoot for technical advice and assistance relating to the dissections and descriptions of the sternal gland and female reproductive system.

\section{Literature Cited}

ClaAk, A. H.

1937. Potent personalities - wasps and hornets. National Geographic, 72: 47-72.

Eisner, T. E., F. McHenry and M. M. Salpeter

1954. Defense mechanisms of arthropods. XV. Morphology of the quinone-producing glands of a tenebrionid beetle (Eleodes longicollis Lec.). J. Morph., 115: 355-399.

Evans, H. E.

1958. The evolution of social life in wasps. Proc. 10th Internat. Congress Ent., Montreal, 2: 449-457.

1964 Observations on the nesting behavior of Moniaecera asperata (Fox) (Hymenoptera, Sphecidae, Crabroninae) with comments on communal nesting in solitary wasps. Insectes Sociaux, 11: 71-78.

1966. The behavior patterns of solitary wasps. Ann. Rev. Ent., 11: 123-154.

Evans, H. E. and R. W. Matthews

1968. The larvae of Microstigmus comes, with comments on its relationship to other pemphredonine genera (Hymenoptera, Sphecidae). Psyche, in press.

Hamilton, W. D.

1964. The genetical evolution of social behaviour. I, II. J. Theoret. Biol., 7 : 1-52.

Howes, P. G.

1925. Master architects of the jungle. Nature Mag., 6: 274-276.

1933. Some insect contrasts. How some social wasps differ in their life habits from some of the solitary species. Nat. Hist., 33: 95-102.

IWATA, K.

1964. Egg giantism in subsocial Hymenoptera, with ethological discussion on tropical bamboo carpenter bees. Nature and Life in Southeast Asia, 3: 399-434.

Krombein, K. V.

1967. A new Collembola-hunting Microstigmus with notes on M. guianensis Rohwer (Hymenoptera, Sphecidae). Ent. News, 78(10): 253-256. 
LEOPOLD, A. S.

1959. Wildlife of Mexico. Univ. Calif. Press. 568 pp.

Masuda, H.

1939. Biological notes on Pison iwatai Yasumatsu. Mushi 12:114-146. MatThews, R. W.

1968. Microstigmus comes: sociality in a sphecid wasp. Science, 160: 787-788.

MedLeR, J. T.

1967. Biology of Trypoxylon in trap nests in Wisconsin (Hymenoptera: Sphecidae). Amer. Midl. Nat., 78: 344-358.

Michener, C. D.

1958. The evolution of social behavior in bees. Proc. 10th Internat. Congress Ent., Montreal, 2: 441-447.

1964. Reproductive efficiency in relation to colony size in hymenopterous societies. Insectes Sociaux, 11: 317-342.

Myers, J. G.

1934. Two Collembola-collecting crabronids in Trinidad. Trans. Roy. Ent. Soc. London, 82: 23-26.

RICHARDS, O. W.

1932. A note on the genus Microstigmus Ducke, with the description of a new species. Ann. Mag. Nat. Hist., (10) 9: 372-377

1935. Two new parasites of aculeate Hymenoptera from Trinidad. Stylops, 4: 131-133.

1965. Concluding remarks on the social organization of insect communities, in P. E. Ellis, ed., Social Organization of Animal Communities, pp. 169-172, Symp. Zool. Soc. London, no. 14.

WEST, M. J.

1967. Foundress associations in polistine wasps: dominance hierarchies and the evolution of social behavior. Science, 157: 1584-1585.

Wilson, E. O.

1966. Behaviour of social insects, in P. T. Haskell, ed., Insect Behaviour, pp. 81-96, Roy. Ent. Soc. London. 

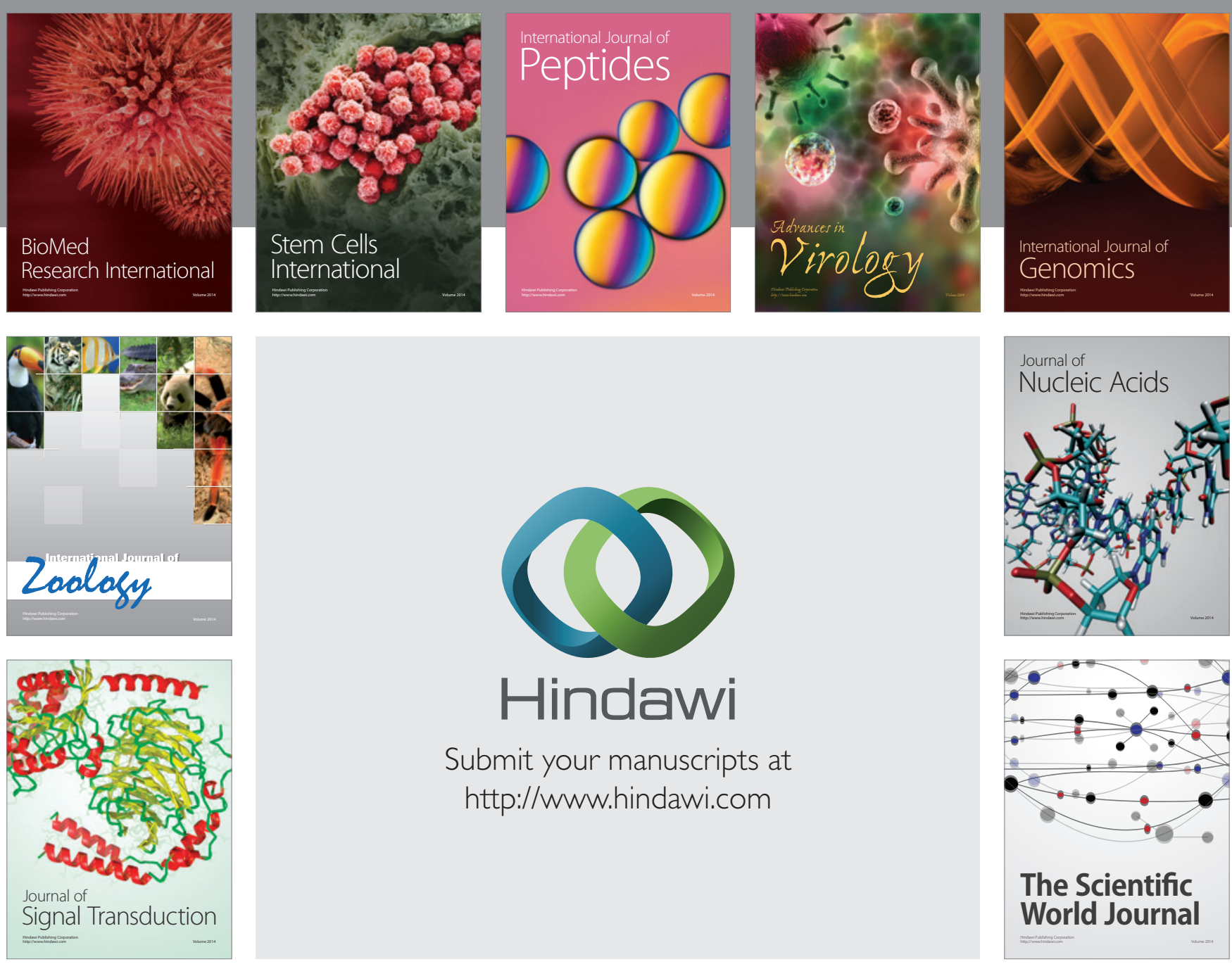

Submit your manuscripts at

http://www.hindawi.com
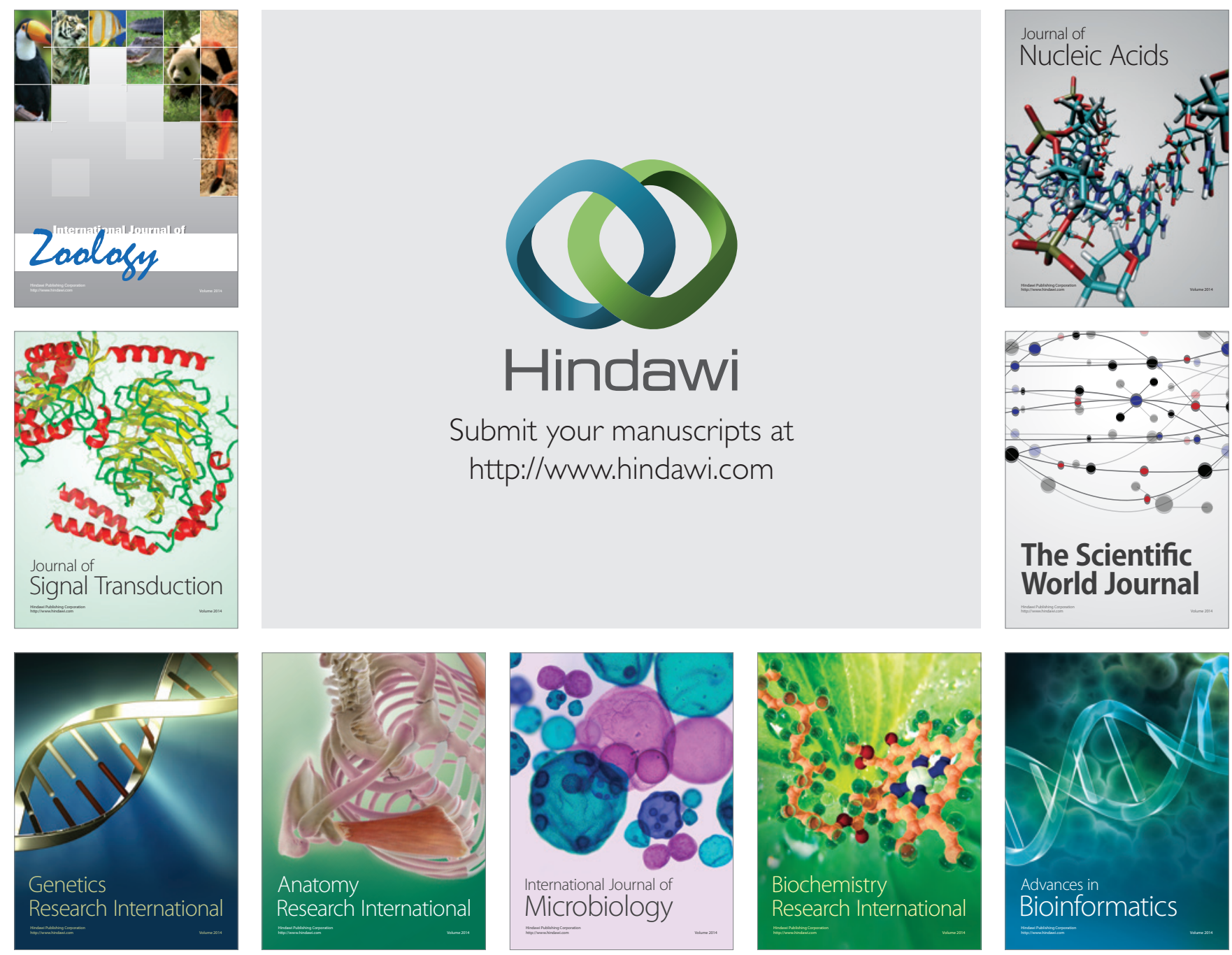

The Scientific World Journal
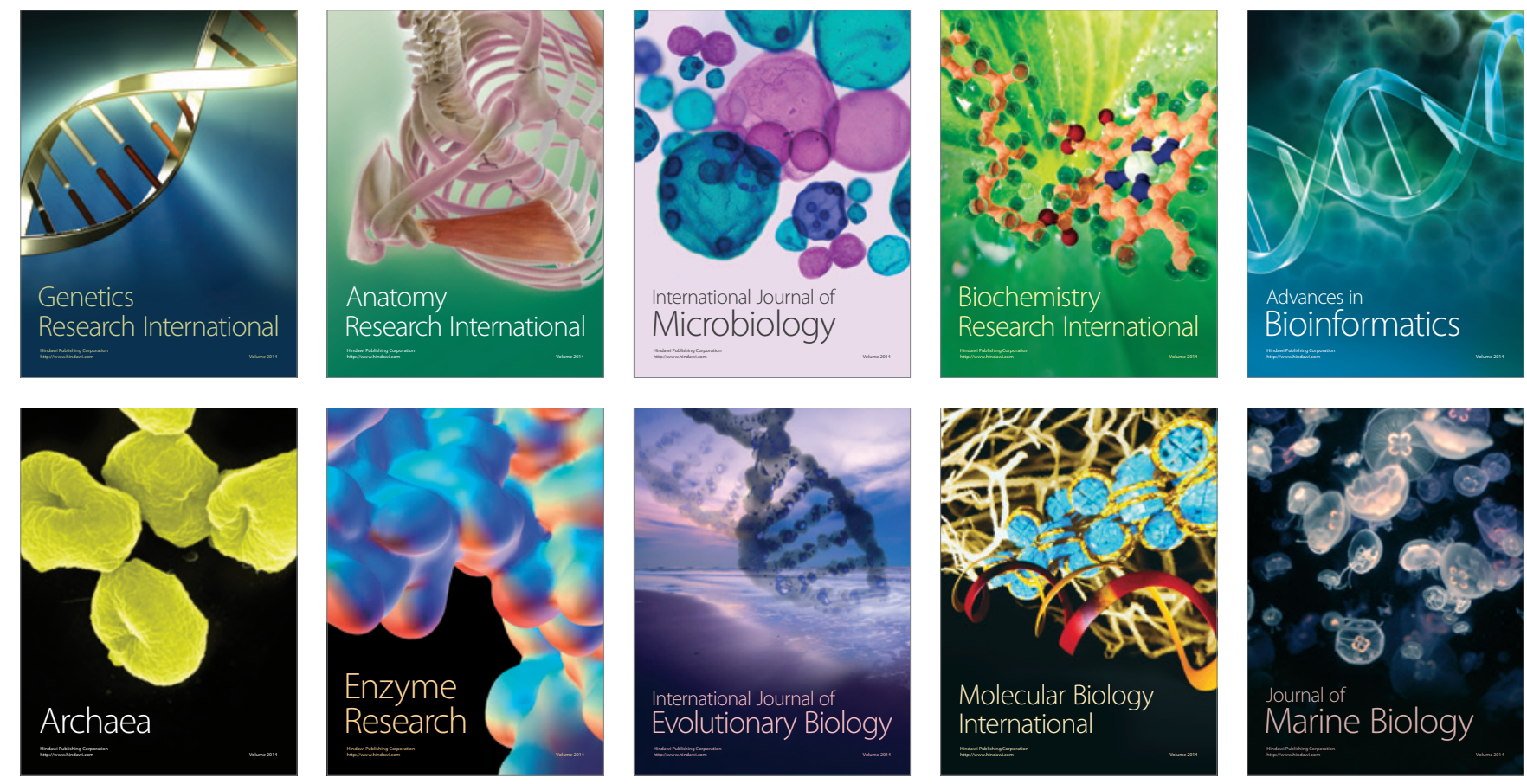